\title{
Maro lepidus Casemir, 1961, a newly recorded spider species (Araneae, Linyphiidae) for Poland
}

\author{
Konrad WIŚNIEWSKI and Wanda WESOLOWSKA \\ Department of Biodiversity and Evolutionary Taxonomy, University of Wroctaw, \\ Przybyszewskiego 63/77, 51-148 Wroctaw, Poland \\ e-mail:konrad.wisniewski@biol.uni.wroc.pl,
}

\begin{abstract}
Maro lepidus Casemir, 1961, a new linyphiid species for Poland is recorded and described. Its distribution and characteristic habitats are discussed and a few remarks on the other two members of the genus Maro (M. minutus, M. sublestus) in Poland are also given.
\end{abstract}

Key words: Araneae, Linyphiidae, Maro lepidus, Poland

\section{INTRODUCTION}

Maro O.P.-Cambridge, 1906 (revised by Saaristo 1971) is a genus comprising 16 Holarctic species (2 Nearctic and 14 Palaearctic - Platnick 2012, Tanasevitch 2012). Four of them have been reported in central Europe up to now, namely Maro lehtineni Saaristo, 1971, M. lepidus Casemir, 1961, M. minutus O.P.-Cambridge, 1906 and M. sublestus Falconer, 1915 (Fauna Europaea 2012). However, only the two latter species have been noted from Poland so far (Kupryjanowicz 2008). Maro lepidus was found during a study of spider assemblages inhabiting mountainous mires in south-western Poland, in Karkonosze (Giant Mountains, ger. Riesengebirge), Izera Mountains and Góry Stolowe (Table Mountains, ger. Heuscheuergebirge). It is the first record of this spider species for this country.

\section{MATERIAL AND METHODS}

188 specimens were caught by means of pitfall traps (among them only three females). All specimens were captured in spring (from April to early June; see the Table 1). Other habitats than mires were not studied in this research, which is still in progress. M. lepidus was also recorded by Robert Rozwalka (unpubl. data, personal comm.) in Beskid Wyspowy Mountains, in a valley of the river Łososina, nearby Kamionka Mala $\left(49^{\circ} 46^{\prime} \mathrm{N}, 20^{\circ} 30^{\prime} \mathrm{E}, 510 \mathrm{~m}\right.$ a.s.l) in late July 2007 (a single female). M. lepidus is easily distinguished by its structure of genitalia, especially by the shape of lamella characteristica in male (Figs 1-7). Additionally, this species might have been omitted in previous researches, due to the very small body-size, ranging from 1.1 to $1.2 \mathrm{~mm}$ in adult males and $1.2-1.4 \mathrm{~mm}$ in females (Roberts 1993), and because of inhabiting sheltered places and its concealed way of life.

\section{DISTRIBUTION OF MARO LEPIDUS}

$M$. lepidus seems to be a rare species, endangered predominately by disturbance of its habitats (Spider and Harvestman Recording Scheme website 2012). The nearest place from which it has been reported so far is the Czech part of the Izera Mountain range (Buchar 1989, 
after Kůrka 1999) and in Karkonosze (Buchar 1967, Kůrka \& Szymkowiak 2007, Kůrka \& Vaněk 2008). It has been also found in Slovakia (Svaton \& Gajdoš 2004).

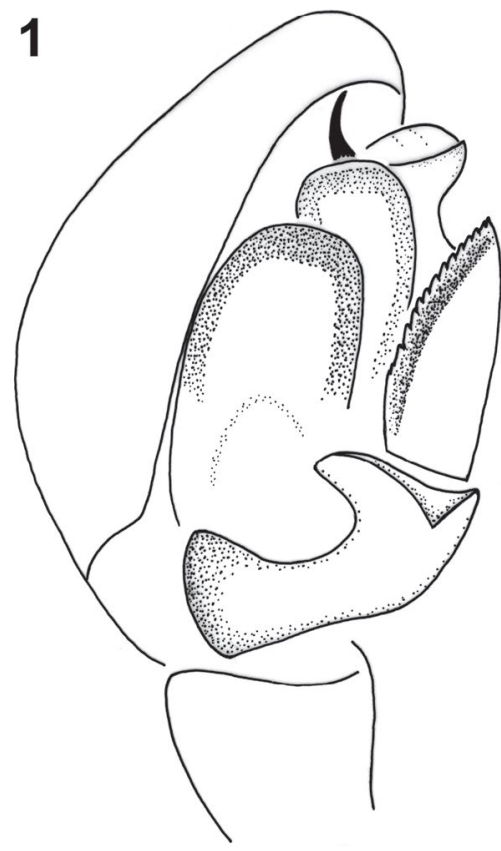

3

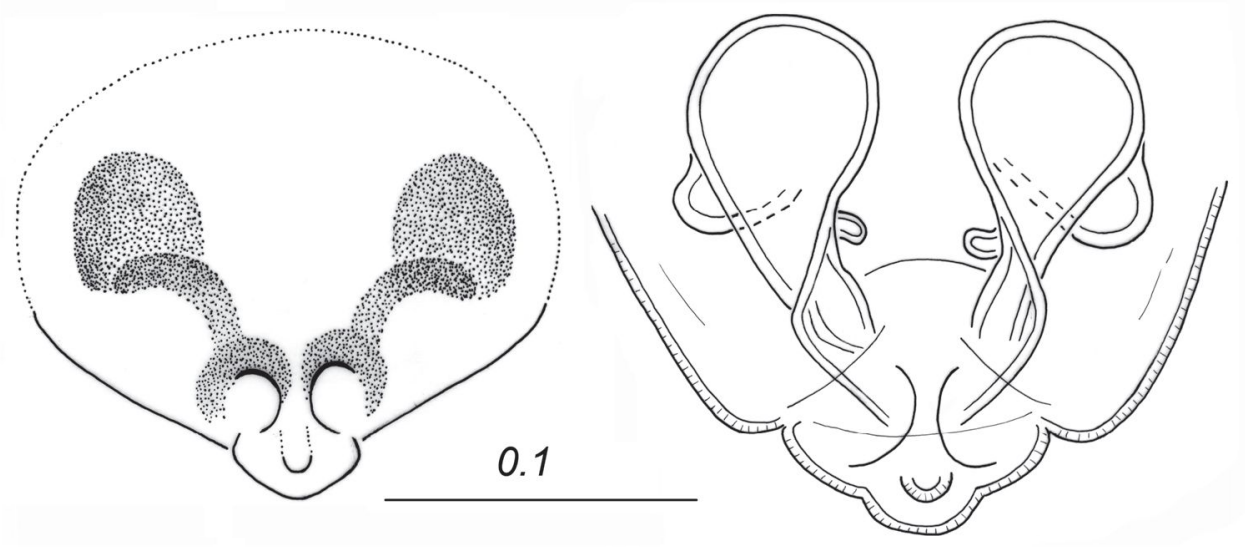

Figs 1-4. Maro lepidus genitalia: 1 - male palp laterally, 2 - male palp ventrally, 3 - epigyne, 4 - vulva (scale bar 0.1 $\mathrm{mm})$.

This species, described by Casemir $(1961,1963)$ in Germany, is also present in other localities in Czech Republic (Kůrka et al. 2006), Austria, Belgium, Germany, Switzerland (Blick et al. 2004), Denmark (Gajdos \& Toft 2002; Scharff 2010), Estonia (Vilbaste 1987), Finland (Saaristo 1971, Koponen 2002), Great Britain (Roberts 1993), Norway (Pommeresche 
2002) and Sweden (Schikora 2003, Almquist 2005). Thus, the known distribution of this species is restricted to central and northern Europe. Poland, Estonia and Finland are at the eastern border of its known range. Considering the geographical distribution of this spider species, it could be expected that it also might be found in other localities in Poland and the Baltic states, especially in north-eastern Poland and Polish mountains. Many Maro species might have a boreo-mountainous distribution (Eskov 1991, after Szymkowiak 2004) and in central Europe M. lepidus is associated with mountains. The limiting factor for this species seems to be also the availability of appropriate habitats.
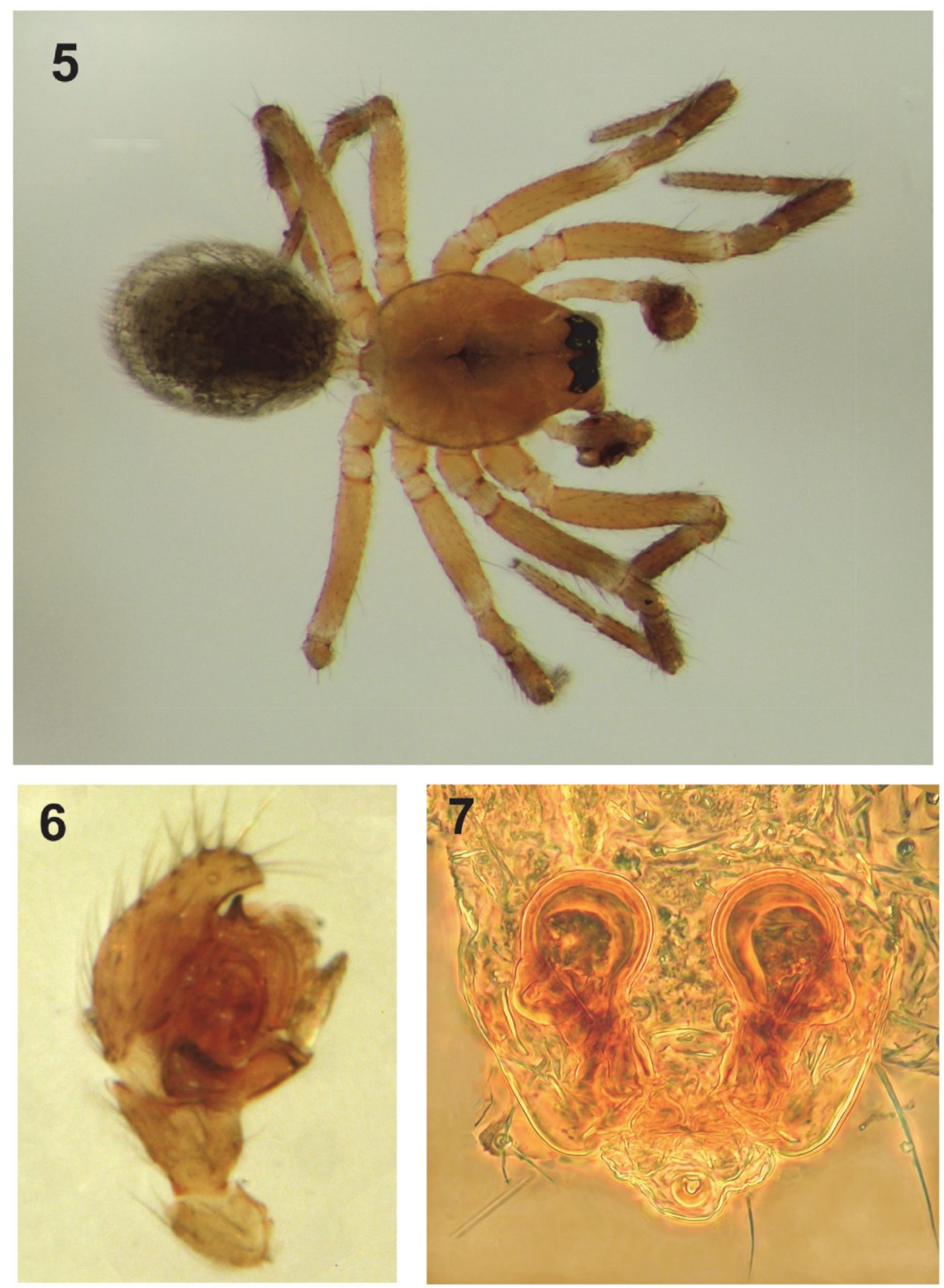

Figs 5-7. Maro lepidus: 5 - male, dorsal view, 6-male palp, lateral view, 7-epigyne 
Table 1. Characteristics of the mire locations, where Maro lepidus was found.

\begin{tabular}{|c|c|c|c|c|c|}
\hline Mountain Range & Geographic coordinates & $\begin{array}{c}\text { UTM } \\
\text { square }\end{array}$ & $\begin{array}{l}\text { Elevation } \\
\text { a.s.1. }[\mathrm{m}] \\
\end{array}$ & $\begin{array}{l}\text { Exposure time of } \\
\text { pitfall traps }\end{array}$ & $\begin{array}{c}\text { Number of specimens } \\
\text { males/females }\end{array}$ \\
\hline Góry Stołowe & $50^{\circ} 27.285^{\prime} \mathrm{N}, 16^{\circ} 22.727^{\prime} \mathrm{E}$ & WR99 & 722 & $09.04-30.04 .2011$ & $9 / 1$ \\
\hline \multirow{10}{*}{ Izera Mountains } & $50^{\circ} 50.390^{\prime} \mathrm{N}, 15^{\circ} 22.200^{\prime} \mathrm{E}$ & WS 23 & 833 & $25.04-09.05 .2010$ & $1 / 0$ \\
\hline & $50^{\circ} 50.210^{\prime} \mathrm{N}, 15^{\circ} 22.474^{\prime} \mathrm{E}$ & WS23 & 835 & $25.04-09.05 .2010$ & $5 / 0$ \\
\hline & $50^{\circ} 50.928^{\prime} \mathrm{N}, 15^{\circ} 22.238^{\prime} \mathrm{E}$ & WS23 & 846 & $23.04-09.05 .2011$ & $3 / 0$ \\
\hline & $50^{\circ} 51.496^{\prime} \mathrm{N}, 15^{\circ} 22.666^{\prime} \mathrm{E}$ & WS23 & 878 & $26.04-24.05 .2010$ & $6 / 0$ \\
\hline & & & & $22.04-10.05 .2011$ & $30 / 0$ \\
\hline & $50^{\circ} 52.400^{\prime} \mathrm{N}, 15^{\circ} 21.385^{\prime} \mathrm{E}$ & WS23 & 960 & $22.04-10.05 .2011$ & $19 / 0$ \\
\hline & $50^{\circ} 52.550^{\prime} \mathrm{N}, 15^{\circ} 20.725^{\prime} \mathrm{E}$ & WS23 & 970 & $26.04-09.05 .2010$ & $13 / 0$ \\
\hline & & & & $22.04-10.05 .2011$ & $6 / 0$ \\
\hline & $50^{\circ} 51.370^{\prime} \mathrm{N}, 15^{\circ} 23.454^{\prime} \mathrm{E}$ & WS23 & 975 & $26.04-12.06 .2010$ & $23 / 1$ \\
\hline & & & & $22.04-10.05 .2011$ & $21 / 0$ \\
\hline \multirow[t]{5}{*}{ Karkonosze } & $50^{\circ} 47.307^{\prime} \mathrm{N}, 15^{\circ} 31.890^{\circ} \mathrm{E}$ & WS32 & 1160 & $26.04-26.05 .2011$ & $9 / 0$ \\
\hline & $50^{\circ} 46.075^{\prime} \mathrm{N}, 15^{\circ} 41.255^{\prime} \mathrm{E}$ & WS42 & 1210 & 27.04-12.05.2011 & $15 / 0$ \\
\hline & $50^{\circ} 47.672^{`} \mathrm{~N}, 15^{\circ} 28.672^{\prime} \mathrm{E}$ & WS32 & 1213 & $25.04-08.05 .2011$ & $5 / 0$ \\
\hline & $50^{\circ} 47.371^{\prime} \mathrm{N}, 15^{\circ} 30.015^{\prime} \mathrm{E}$ & WS32 & 1252 & $25.04-08.05 .2011$ & $5 / 1$ \\
\hline & $50^{\circ} 44.890^{\prime} \mathrm{N}, 15^{\circ} 41.460^{\prime} \mathrm{E}$ & W: & 1410 & 28.04-31.05.2011 & $15 / 0$ \\
\hline
\end{tabular}

\section{ChaRACTERISTIC HABITATS}

M. lepidus is often referred to as tyrphobiont species i.e. it is associated with peat bogs (Casemir 1976). In the present study it inhabited mires in the Izera River valley and on the slopes of the Izera Mountains, sloping and subalpine mires in Karkonosze and it was also found on Wielkie Torfowisko Batorowskie (Great Batorowskie Bog) in Góry Stolowe. The mire types were: open poor fens within grassland habitats, poor fens surrounded by mountain pine (Pinus mugo Turra; in the Izera Valley this species grows also on $830 \mathrm{~m}$ a.s.1.), mires sparsely covered by spruce (Picea abies (L.) H. Karst) forest, open mires surrounded by spruce forest and subalpine mires, surrounded by mountain pine. The first two habitat types are to be found in the Izera River valley (in the nature reserve "Torfowiska Doliny Izery" - "The Mires of the Izera Valley"), the next two habitats are situated on the slopes of the Izera Mountains and Karkonosze, at different altitudes from $880 \mathrm{~m}$ a.s.1., up to about $1210 \mathrm{~m}$ a.s.l., the last one - above forest level (see Table 1). In the Gory Stolowe this was a spruce swamp forest. However, the strong association of $M$. lepidus with mires and their being a - so called indicator species for these habitats should be the matter of discussion (Neet 1996). This species was reported from different types of mires, such as peat bogs and poor fens (both forested and open - Blandenier 1996, Casemir 1976, Koponen 2002, Schikora 2003, Svaton \& Gajdoš 2004, Ko̊rka \& Vaněk 2008), although it was also found in other habitats, such as alder wood (Komposch 2000, Kürka et al. 2006) or reed bed (Kürka et al. 2006), and in the present recording by Robert Rozwalka that has been mentioned above - in a moist moss. However, it surely might be considered as a sphagnophilous species (the one preferring mires) that very rarely occurs in other habitats.

\section{GENUS MARO IN POLAND}

The two other species of Maro known from Poland - M. minutus and M. sublestus - were also collected during the present study. M. minutus is a widespread species found throughout the territory of Poland (Kupryjanowicz 2008). In this study (172 specimens in total) it was most abundant on two subalpine mires in Karkonosze (on Śnieżka Plateau, 50 $44.342^{\prime} \mathrm{N}$ $15^{\circ} 42.476^{\prime} \mathrm{E}, 1435 \mathrm{~m}$. a.s.1. and on the bog in $50^{\circ} 47.371^{\prime} \mathrm{N} 15^{\circ} 30.015^{\prime} \mathrm{E}$, where it cohabited with $M$. lepidus) and on a bog in the Izera Mountains (50 51.890'N 15'21.682'E, $915 \mathrm{~m}$ a.s.1.). $M$. minutus was also found together with $M$. lepidus - in addition to the above-mentioned bog 
- on one mire in the Izera valley. M. sublestus was reported from Poland only in Western Sudety Mountains (Szymkowiak 2004, Kupryjanowicz 2008). In the present study 5 specimens of this species were identified. They lived on one mire in Karkonosze (a so called Bagnisko, in Jakuszyce, $50^{\circ} 49.530^{\prime} \mathrm{N} 15^{\circ} 26.593^{\prime} \mathrm{E}, 853$ a.s.1.) and they were also found together with $M$. lepidus in two places $\left(50^{\circ} 46.075^{\prime} \mathrm{N} 15^{\circ} 41.255^{\prime} \mathrm{E}, 50^{\circ} 51.370^{\prime} \mathrm{N} 15^{\circ} 23.454^{\prime} \mathrm{E}\right)$.

M. minutus and $M$. sublestus seem to be strictly hygrophilous species. They are also epigeic spiders and alike $M$. lepidus, $M . m$. and $M . s$. might have an affinity to forest habitats (Kupryjanowicz 2008). They were present both on open and sparsely forested mires that were surrounded by forest or mountain pine shrubs.

\section{ACKNOWLEDGEMENTS}

Maro lepidus was found during the study of spider assemblages inhabiting various mountainous mires. This study is carried out with permissions of the Karkonosze National Park, the Ministry of Environment, Regional Directorate for Environmental Protection in Wroclaw and Stolowe Mountains National Park.

\section{REFERENCES}

ALMQUST S. 2005. Swedish Araneae, part 1 - families Atypidae to Hahniidae. Insect Systematics \& Evolution, Supplement No. 62, 284 pp.

Blandenter G. 1996. Première mention suisse de Maro lepidus Casemir, 1961 (Arachnida, Araneae, Linyphiidae) et aperçu de son écologie. Bulletin de la Société Neuchateloise des Sciences Naturelles 119: 59-61.

Blick T., Bosmans R., Buchar J., Gaddoš P., Hänggi A., VAN Helsdingen P., RŮŽičKa V., STAREgA W. \& THALER K. 2004. Checkliste der Spinnen Mitteleuropas. Checklist of the spiders of Central Europe. (Arachnida: Araneae). Version 1., December 2004, http://www.arages.de/checklist.html\#2004_Araneae.

BUChar J. 1967. Pavouci fauna Pančické Louky a blízkeho okolí. Opera Corcontica 4: 79-93.

BUCHAR J. 1989. Poznání současné arachnofauny Čech a jeho využití $\mathrm{k}$ posouzení vývoje př́rodních poměrů. $\mathrm{PhD}$ thesis, Charles University, Faculty of Science, Praha, 206 pp. [in Czech]

CASEMIR H. 1961. Einige für Deutschland neue und seltene Spinnenarten. Zoologischer Anzeiger 166: $195-206$.

CASEMRR H. 1963. Maro lepidus n. sp., eine neue Spinnenart aus der Gattung Maro Cambr. 1906 (Linyphiidae). Zoologischer Anzeiger 170: 159-164.

CASEMIR H. 1976. Beitrag zur Hochmoor-Spinnenfauna des Hohen Venns (Hautes Fagnes) zwischen Nordeifel und Ardennen. Decheniana 129: 38-72.

EsKov K. Y. 1991. On the taxonomy and zoogeography of the spider genera Maro and Oreonetides (Aranei, Linyphiidae). Zoologitscheskii Zhurnal 70 (4): 45-54 [In Russian, English summary].

FAUNA EUROPEA, http://www.faunaeur.org/ (12.01.2012).

GAJDOŠ P. \& TOFT S. 2002. Distinctiveness of the epigeic spider communities from dune habitats on the Danish North Sea coast. In: TOFT S. \& SCHARFF N. (eds), European Arachnology 2000 (Proceedings of the 19th European Colloquium of Arachnology, Aarhus 17-22 July 2000), pp. 223-228. Aarhus University Press, Arhus, 358 pp.

KomposcH C. 2000. Harvestmen and spiders in the Austrian wetland Hörfeld moor (Arachnida: Opiliones, Araneae). Ekológia (Bratislava) 19, Supplement 4: 65-77.

KOPONEN S. 2002. Spider fauna of peat bogs in southwestern Finland. In: TOFT S. \& SCHARFF N. (eds), European Arachnology 2000 (Proceedings of the 19th European Colloquium of Arachnology, Aarhus 17-22 July 2000), pp. 267-271. Aarhus University Press, Arhus, 358 pp.

Kupryjanowicz J. 2008. Pająki, Araneae. In: Bogdanowicz W., Chudzicka E., PLIPIUk I. \& SkIBIŃska E. (eds), Fauna Polski. Charakterystyka i wykaz gatunków, pp. 223-239. Muzeum i Instytut Zoologii PAN, Warszawa, 603 pp.

KŮRKA A. 1999. Pavouci (Áraneida) Chráněné krajinné oblasti Jizerské hory. Sborník Severočeského Muzea, Přírodni Vědy 21: 119-136.

KŮRKA A., BUCHAR J., KuBCovÁ L. \& BRYJA V. 2006. Pavouci (Araneae) CHKO Kokořinsko. Bohemia centralis 27: 91-135.

KŮRKA A. \& VANĚK J. 2008. Pavouci (Araneae) krkonošských lesních rašeliništ'. Opera Corcontica 45: $125-149$.

KŮRKA A. \& SZYMKOWIAK P. 2007. Pavouci. In: ŠMATLAK J. \& ZYKÁNOVÁ J. (eds), Krkonoše - př́roda, historie, Život, pp. 235-240. Praha, Baset, 864 pp. [See also the table attached to the book on a CD].

NEET C. R. 1996. Spiders as indicator species: lessons from two case studies. Revue Suisse de Zoologie, hors série: 501-510.

PLATNICK N. I. 2012. The world spider catalog, version 12.5. American Museum of Natural History, http://research.amnh.org/iz/spiders/catalog (12.01.2012). 
POMMERESCHE R. 2002. Spider species and communities in bog and forest habitats in Geitaknottane Nature Reserve, Western Norway. In: TOFT S. \& SCHARFF N. (eds), European Arachnology 2000. Proceedings of the 19th European Colloquium of Arachnology, Aarhus 17-22 July 2000), pp. 199-205. Aarhus University Press, Århus, 358 pp.

ROBERTS M. J. 1993. The spiders of Great Britain and Ireland. Harley Books. Vol. 2. Linyphiidae and Check List, 204 pp.

SAARTSTO M. I. 1971. Revision of the genus Maro O. P.-Cambridge (Araneae, Linyphiidae). Annales Zoologici Fennici 8: 463-482.

SCHARFF N. 2010. Checklist of Danish Spiders (Araneae): http://www.zmuc.dk/entoweb/arachnology/dkchecklist.htm (Version 10-06-2010).

SCHKKORA H. B. 2003. Spinnen (Arachnida, Araneae) nord- und mitteleuropäischer Regenwassermoore entlang ökologischer und geographischer Gradienten. Verlag Mainz, Wissenschaftsverlag, Aachen, 567 pp.

Spider and Harvestman Recording Scheme website 2012: http://srs.britishspiders.org.uk/portal.php/p/Summary/s/Maro\%20lepidus (15.08.2012).

SVATON J. \& GAJDOS P. 2004. Spiders of peatland ecosystems of the Horna Orava region (Slovakia). In: SAMU F. \& SZINETÁR C. (eds), European Arachnology 2002 (Proceedings of the 20th European Colloquium of Arachnology, Szombathely 22-26 July 2002), pp. 275-284. Plant Protection Institute, Budapest and Berzsenyi College, Szombathely, Budapest, $356 \mathrm{pp}$.

SZYMKOWIAK P. 2004. Maro sublestus Falconer, 1915 (Araneae, Linyphiidae) - a spider new to the fauna of Poland Fragmenta Faunistica Musei Zoologici Polonici 47: 139-142.

TANASEVITCH A. V. 2012. Linyphiid spiders of the world: http://www.andtan.newmail.ru/list/ (12.01.2012).

VILBAStE A. 1987. Eesti Ämblikud (Aranei). Annoteeritud nimestik [Estonian spiders - an annotated checklist.] Tallinn, Valgus, 113 pp. (+ maps).

\section{STRESZCZENIE}

\section{[Maro lepidus Casemir, 1961 nowy dla Polski gatunek pająka (Araneae, Linyphiidae)]}

Maro lepidus został odnaleziony na terenie Polski. 188 osobników tego gatunku (w tym trzy samice) zostały schwytane przy pomocy pulapek Barbera, podczas badań zgrupowań pająków na torfowiskach górskich Sudetów Zachodnich i Środkowych (inne środowiska, niż torfowiska nie byly badane). Gatunek ten był notowany już w czeskiej części tych gór, jest również znany w wielu krajach europejskich. $M$. lepidus występuje prawie wylącznie na torfowiskach, choć znane są pojedyncze stwierdzenia z innych środowisk, takich jak ols czy trzcinowiska. W Polsce występuja jeszcze dwa gatunki z rodzaju Maro: szeroko rozpowszechniony M. minutus i znany tylko z Karkonoszy M. sublestus. Oba te gatunki zostaly również odnalezione podczas tych badań, niekiedy wspólwystępowaly one na jednym torfowisku z M. lepidus. 